D. K. Henderson and Dr. Norman Dott, who, supported by the Rockefeller Foundation, were working at Bangour on head injuries. There he continued throughout the war years. Later he worked with Sir Hugh Cairns at the Oxford Head Injuries Unit and also joined the Institute of Experimental Psychology of the University of Oxford, where in due course he became a senior lecturer. The marked development of this Institute during the past few years has been largely due to Mr. 'Zangwill's judicious and successful leadership. His immediate research interests lie chiefly in the study of the connexion of specific psychological functions with cerebral activities, but he is far from being a first-rate specialist only. His article on psychology in the new edition of "Chambers's Encyclopædia" bears comparison with Prof. James Ward's famous contribution on the same subject to an earlier edition of the "Encyclopædia Britannica". His recent book in the Home University Series shows that, while he has decided opinions of his own, he has also a tolerant and wide outlook and an extensive and profound knowledge of psychology which few, if any, of his contemporaries can rival.

\section{Hundred Years of Instrument Making}

THE firm of Negretti and Zambra (122 Regent Street, London, W.1) has issued, in celebration of the completion in 1950 of a century of instrument-making activities, an attractive booklet, containing many historicel illustrations, which provides a brief history of the firm and indicates the milestones in its prcgress. From 1850, the year of its foundation, until 1914, Negretti and Zambra was almost entirely engaged in the development and production of meteorological instruments, and, in the mind of the general public, the firm was perhaps identified with the weather and its vagaries. It is apparent, however, from the account given of the developments and inventions of the firm in this field, that the science of meteorology is in no little debt to this firm. There is also a clear indication of the very personal relations which existed between the scientific instrument maker and the user of scientific instruments before the period when the widely extended use of scientific instruments made the continuance of these relationships very much more difficult. A number of instances are quoted in the centenary booklet of the users of meteorological instruments approaching members of the firm in order to discuss their problems, and Mr. E. A. L. Negretti was often present at the trials of new instruments by, for example, the Admiralty. The exigencies of the First World War imposed upon the firm the task of extending the field of its instruments, and, in particular, Negretti and Zambra commenced the production of process-control instruments. While the firm still retains its relation to meteorology, it is to-day just as well known for the part it plays in the control of industrial processes. The history of this firm provides an excellent illustration of the evolution of the modern seientific instrument industry. Scientific instrument manufacture, which existed in Great Britain before the time of Sir Isaac Newton, pursued an interesting, but placid, course for some centuries. The period of the First World War separates the old scientific instrument industry from the new. To-day it is an industry essential to the health of all other industries, and the account given of the activities of this latest recruit to the select body of British scientific instrument makers having more than a century of continuous existence evokes memories of a more leisurely past while indicating the present very wide field of the usage of scientific instruments.

\section{Chemical Engineering Science: Genie Chimique}

A NEW periodical is apt to arouse suspicion and evoke the question, "Is it really necessary ?" It may be said that two conditions must be fulfilled for a newcomer to be regarded as a journal of importance : the first is that the contents must be of high quality ; and the second that it serves as a medium for publishing work which might not otherwise reach those to whom it is of interest. As regards the first requirement, there can be little doubt of its fulfilment by Chemical Engineering Science: Genie Chimique, an international monthly the first number of which appeared last October (Pergamon Press, Ltd., 2-5 Studio Place, Kinnerton Street, London, S.W.1; $90 s$. a vol.). There are seven editors, all chemical engineers of high standing, residing in France, Great Britain, Italy, Switzerland, Belgium, Holland and Norway, and an advisory board of nineteen from eleven countries. Six original papers of high quality occupy fifty quarto pages very clearly printed by the Würzburg University Press, and it is hoped to publish in English, French or German not only papers dealing with the principles of chemical engineering but also detailed notes on advances in industrial processes. The second requirement may also be regarded as met. As explained by Prof. J. Cathala in an introductory paper, one of the reasons for the recent spectacular successes of the American chemical industry and the swamping effect of American chemical engineering literature is that chemical engineering has for many years been recognized in the United States as a definite and independent branch of technology. In Europe there are many chemical engineers with the highest qualifications; but, particularly on the Continent, they are not often given a distinctive name, and there is no common journal in which their work can be pub. lished. In consequence, much valuable material is apt to be overlooked. British chemical engineers, who already have at least three periodicals to which they themselves normally contribute, will particularly welcome this new and valuable means of bringing to their notice work which is taking place in the countries around them and will wish the new publication every success.

\section{Oceanographical Expedition to the South Atlantic}

It has been announced from the Woods Hole Oceanographic Institution, Woods Hole, Mass., that the research vessels Atlantis and Albatross $I I I$ have recently left Cape Cod, Mass., to make a thorough investigation of the equatorial currents between West Africa and the South American coast. Observations will be made of ocean temperatures and salinity, chemical nutrients in solution in the water, strength and direction of currents, microscopic life and the relation between the trade winds and the ocean currents. The scientific work on board the Atlantis, a $142 \mathrm{ft}$. ketch, will be in the charge of Dr. Bostwick H. Ketchum, a marine bacteriologist, while aboard the Albatross $I I I$, a 185 -ft. steel trawler chartered from the United States Fish and Wildlife Service, Dr. Francis A. Richards, a chemical oceanographer, will be the scientific director. The investigations of ocean currents will be under the supervision of Frederick C. Fuglister and Columbus O'D. Iselin, 